\title{
Keragaman genotipik entok (Cairina moschata) berdasarkan polimorfisme protein darah
}

\author{
Sutopo, Dela Ayu Lestari, Asep Setiaji *, Edy Kurnianto \\ Program Studi Peternakan, Fakultas Peternakan dan Pertanian, Universitas Diponegoro, Semarang, 50275 \\ *Correspondence: asepsetiaji93@gmail.com
}

Received: September $8^{\text {th }}, 2021$; Accepted: November $9^{\text {th }}, 2021$; Published online: November 17 ${ }^{\text {th }}, 2021$

\section{Abstrak}

Tujuan: Penelitian ini bertujuan untuk mengidentifikasi keragaman genetik entok di Jawa Tengah berdasarkan polimorfisme protein darah dengan metode elektroforesis.

Metode: Materi yang digunakan yaitu sampel darah dari 60 ekor entok, masing-masing 20 ekor dari Kabupaten Demak, Magelang dan Pekalongan. Metode elektroforesis Polyacrylamid Gel Electrophoresis -Thin Layer Elecrophoresis (PAGE-TLE) digunakan dalam penelitin ini. Parameter yang diamati adalah protein Albumin (Alb), ceruloplasmin (Cp), transferin (Tf) dan amylase-I (Am-I). Frekuensi gen, heterozigositas (Ho) dan jarak genetik dianalisis dengan menggunakan paket program DISPAN.

Hasil: Hasil analisis menunjukkan bahwa Alb, $\mathrm{Cp}$, Tf dan Am-I pada tiga populasi entok memperlihatkan karakter polimorfik. Frekuensi gen $\mathrm{Alb}^{\mathrm{B}}(0,61)$ lebih tinggi dibandingkan $\mathrm{Alb}^{\mathrm{A}}(0,39)$. Frekuensi gen $\mathrm{Cp}^{\mathrm{A}}(0,62)$ relatif lebih tinggi dibandingkan gen $\mathrm{Cp}^{\mathrm{B}}(0,38)$. Frekuensi gen $\mathrm{Tf}^{\mathrm{A}}$ memiliki nilai sebesar 0,32 dan gen $\mathrm{Tf}^{\mathrm{B}}$ sebesar 0,68 begitu juga Nilai frekuensi Am-IA menunjukkan angka yang lebih tinggi $(0,82)$ dibandingkan gen $\mathrm{Am}-\mathrm{I}^{\mathrm{B}}(0,18)$. Populasi entok Demak memiliki nilai Ho tertinggi pada lokus Alb dan Am-I sedangkan populasi entok Magelang menunjukkan nilai Ho tertinggi pada lokus Cp dan Tf. Populasi entok Demak menunjukkan kedekatan jarak genetik dengan populasi Pekalongan dibandingkan dengan populasi Magelang.

Kesimpulan: Lokus protein darah dari tiga populasi entok di Jawa Tengah bersifat polimorfik.

Kata Kunci: darah entok; elektroforesis; frekuensi gen; jarak genetik; polimorfisme

\section{Abstract}

Objective: The aim of this study was to identified genetic diversity of muscovy duck in Central Java through blood protein polymorphisms by using electrophoresis method.

Methods: Blood sample was collected from a total of 60 muscovy ducks from the districts of Demak, Magelang and Pekalongan, 20 samples each. The Electrophoresis Polyacrylamide Gel of Electrophoresis-Thin Layer Electrophoresis (PAGE-TLE) was used in this study. Parameters observed were protein of albumin (Alb), ceruloplasmin (Cp), transferrin (Tf) and amylase-I (Am-I). Gene frequency, heterozygosity (Ho) and genetic distance were analyzed by using DISPAN program.

Results: The results showed that the Alb, Cp, Tf and Am-I of muscovy duck showing polymorphic characters. Gene frequency of $\mathrm{Alb}^{\mathrm{B}}(0.61)$ was higher compared to $\mathrm{Alb}^{\mathrm{A}}(0.39)$. Gene frequency of $\mathrm{Cp}^{\mathrm{A}}$ (0.62) was higher than the $C \mathrm{p}^{\mathrm{B}}$ (0.38). Furthermore, gene frequency of $\mathrm{Tf}^{\mathrm{A}}$ and $\mathrm{Tf}^{\mathrm{B}}$ were 0.32 and 0.68 , respectively as well as gene frequency of Am-IA $(0.82)$ was higher than Am- $\mathrm{I}^{\mathrm{B}}(0.18)$. Muscovy duck 
population of Demak showed higher Ho value for Alb and Am-I, whereas Magelang showed higher value for $\mathrm{Cp}$ and Tf. Population of muscovy duck of Demak showed closer genetic distance to Pekalongan than Magelang.

Conclusions: The protein blood locus of three population of muscovy duck in Central Jawa showed polymorphic characters.

Keywords: blood; electrophoresis; gene frequency; genetic distance; polymorphism

\section{PENDAHULUAN}

Entok (Cairina moschata) merupakan salah satu jenis ternak unggas yang telah lama dikembangkan oleh peternak rakyat di Indonesia. Data statistik Kementerian Pertanian Republik Indonesia mencatat bahwa produksi daging entok pada tahun 2017 mencapai angka 5,6 ton [1]. Penyebaran entok lokal di Jawa Tengah merata disemua wilayah Jawa Tengah dengan jumlah populasi yang beragam berdasar kondisi geografis dan sosial ekonomi masyarakat [2]. Pengembangan entok sebagai penghasil daging mempunyai prospek yang sangat baik, karena entok mempunyai laju pertumbuhan dan bobot karkas yang lebih baik dibandingkan dengan jenis itik yang lain $[3,4]$. Entok juga mampu beradaptasi dengan baik pada berbagai kondisi lingkungan dan lebih tahan terhadap penyakit dibandingkan unggas lain [5]. Disisi lain, entok belum banyak mendapatkan proses pemuliaan seperti halnya komuditas unggas yang lain. Informasi keanekaragaman genetik sangat dibutuhkan sebagai informasi awal untuk proses pemuliaan.

Keanekaragaman adalah hasil interaksi antara pengaruh genetik dan lingkungan pada diferensiasi sifat morfologis, fisiologis dan produktif yang penting untuk semua sistem produksi [6]. Polimorfisme protein darah masih sangat diperlukan di negara berkembang, meskipun karakterisasi keragaman genetik ternak menggunakan penanda mikrosatelit dan prosedur teknologi yang lebih tinggi telah dilakukan. Keunggulan analisis ini adalah kegunaannya dalam mengetahui informasi genetik, biaya yang murah, dan interpretasi data yang sederhana [7]. Polimorfisme protein darah telah banyak digunakan untuk studi karakterisasi genetik dan filogenetik ternak lokal di Indonesia [8] pada kambing, [9] pada ayam Kedu, [10] pada itik Pegagan, [11] pada domba, [12,13] pada sapi.

Penelitian karakterisasi keragaman dan estimasi jarak genetik pada entok masih sangat terbatas. Tujuan penelitian ini adalah untuk mengetahui dan mengidentifikasi keragaman genetik melalui polimorfisme protein darah dengan metode elektroforesis pada entok di Jawa Tengah. Manfaat dari penelitian ini diharapkan mampu memberikan informasi keragaman genetik yang dapat digunakan dalam program seleksi.

\section{MATERI DAN METODE}

\section{Materi}

Pengambilan data dilakukan di tiga Kabupaten di Jawa Tengah, bagian timur (Kabupaten Demak), bagian tengah (Kabupaten Magelang) dan bagian timur (Kabupaten Pekalongan). Materi yang digunakan dalam penelitian ini adalah 60 ekor entok lokal. Sampel darah diambil dari 20 ekor entok masing-masing di setiap populasi terdiri dari 10 ekor entok jantan dan 10 ekor entok betina.

\section{Pengambilan sampel darah}

Pengambilan sampel darah dilakukan dengan menggunakan spuit sebanyak 2-3 $\mathrm{ml}$ pada bagian vena brachialis di bagian sayap [14] kemudian darah ditampung dalam vaccutube. Pemisahan serum darah dilakukan dengan dicentrifuge pada kecepatan $3500 \mathrm{rpm}$ selama 7 menit. Serum darah dipindahkan dalam microtube lalu dimasukkan dalam refrigerator pada suhu $5^{\circ} \mathrm{C}$.

\section{Proses elektroforesis}

Analisis protein darah dilakukan dengan mengunakan elektroforesis Polyacrylamid Gel Electrophoresis -Thin Layer Eletrophoresis (PAGE-TLE) sesuai metode [15] dengan 
beberapa modifikasi. Serum darah diencerkan menggunakan aquades dengan perbandingan $1 \mu \mathrm{L}: 13 \mu \mathrm{L}$ dan dicampur dengan blue juice dengan perbandingan 4:1. Sampel kemudian dipanaskan diatas waterbath dengan suhu $100^{\circ} \mathrm{C}$ selama 3 menit dan kemudian didinginkan diatas air es. Sebanyak $10 \mu \mathrm{L}$ serum darah yang sudah diencerkan dimasukkan kedalam gel dan dilakukan running electrophoresis dengan voltase $125 \mathrm{~V}$ selama 3 jam. Gel kemudian diwarnai menggunakan staining solution ( $20 \mathrm{ml}$ Glacial Acetic Acid, $80 \mathrm{ml}$ Methanol, $100 \mathrm{ml}$ Aquadest, $0.2 \mathrm{~g}$ Coomassie Blue) selama 1 jam menggunakan shaker dan dilakukan destaining menggunakan destaining solution (20 ml Glacial Acetic Acid, $80 \mathrm{ml}$ Methanol, $100 \mathrm{ml}$ Aquadest) selama $2 \times 45$ menit. Pita protein darah yang terlihat dari hasil proses elektroforesis digunakan untuk menghitung frekuensi gen, heterosigositas pengamatan dan jarak genetik. Pita-pita hasil elektroforesis yang diamati adalah albumin (Alb), ceruloplasmin (Cp), transferin (Tf) dan amylase-I (Am-I).

\section{Analisis data}

Frekuensi gen, merupakan perbandingan suatu alel pada lokus yang sama pada satu populasi [16], dapat dihitung dengan rumus:

$$
\mathrm{F}_{\mathrm{An}}=\frac{\sum \operatorname{lokus}_{\mathrm{An}}}{\sum \text { lokus }_{\mathrm{A} 1}+\sum \operatorname{lokus}_{\mathrm{A} 2}+\sum \operatorname{lokus}_{\mathrm{An}}}
$$

Keterangan:

$\mathrm{F}_{\mathrm{An}}=$ frekuensi gen A pada lokus ke-n

Heterosigositas, dalam hal ini Ho merupakan salah satu parameter yang dapat digunakan untuk mengukur tingkat keragaman genetik dalam suatu populasi [17], dapat ditentukan dengan menggunakan rumus:

$$
\begin{gathered}
\mathrm{Ho}=1-\sum q_{i}{ }^{2} \\
\overline{\mathrm{H}}=\frac{\sum \mathrm{h}}{\mathrm{r}}
\end{gathered}
$$

Keterangan:

Ho $=$ heterosigositas individual $\mathrm{r} \quad$ = jumlah lokus yang diamati

$\overline{\mathrm{H}}=$ rerata heterosigositas

Jarak genetik, digunakan untuk memperkirakan waktu terjadinya pemisahan antar populasi dan untuk membentuk pohon filogenetik. Jarak genetik antar populasi (D) dihitung berdasarkan rumus [18]:

$$
\mathrm{D}=-\log _{\mathrm{e}} \mathrm{I} \text { dan } \mathrm{I}=\sqrt{\frac{\sum \mathrm{X}_{\mathrm{ij}} \mathrm{Y}_{\mathrm{ij}}}{\left(\sum \mathrm{X}_{\mathrm{ij}}{ }^{2}\right)\left(\sum \mathrm{Y}_{\mathrm{ij}}{ }^{2}\right)}}
$$

Keterangan:

$\mathrm{X}_{\mathrm{ij}}=$ frekuensi alel ke $\mathrm{i}$ pada lokus $\mathrm{j}$ dari populasi $X$

$Y_{i j}=$ frekuensi alel ke $\mathrm{i}$ pada lokus $\mathrm{j}$ dari populasi $Y$.

\section{HASIL}

Pengamatan terhadap empat pita hasil elektroforesis; Alb, Cp, Tf dan Am-I dipilih berdasarkan hasil identifikasi terhadap enam lokus. Dari hasil identifikasi, hanya empat lokus tersebut yang terlihat dengan jelas seperti yang ditampilkan pada Gambar 1 . Berdasarkan hasil elektroforesis, dapat diketahui bahwa masing-masing lokus memiliki sifat polimorfik karena memiliki dua alel atau lebih dalam populasi yang sama. Distribusi frekuensi genotip protein darah pada entok di tiga kabupaten di Jawa Tengah dapat dilihat masing-masing pada Tabel 1. Hasil heterosigositas pengamatan dapat dilihat pada Tabel 2. Ho lokus Alb, Cp, Tf dan Am-I pada entok tergolong rendah berkisar antara 0,402-0,454.

Peta pengelompokkan pada entok di tiga kabupaten berbeda di Jawa Tengah menunjukkan bahwa penyebaran entok berdasarkan sebaran genotip berada di dalam garis pemisah yang tidak jauh berbeda (Gambar 2). Penyebaran populasi entok di Kabupaten Pekalongan, Demak, dan Magelang menunjukkan penyebaran yang merata dan tidak jauh berbeda. Hasil analisis kekerabatan pada Gambar 3. Menunjukkan bahwa populasi entok Demak memiliki kedekatan dengan populasi entok Pekalongan dan sedikit berbeda dengan populasi entok Magelang. 
Tabel 1. Frekuensi genotip protein darah pada entok di tiga kabupaten di Jawa Tengah

\begin{tabular}{|c|c|c|c|c|c|c|}
\hline \multirow{2}{*}{ Lokus $^{1}$} & \multirow{2}{*}{ Genotip } & \multicolumn{3}{|c|}{ Kabupaten } & \multirow{2}{*}{ Total } & \multirow{2}{*}{$\begin{array}{c}\text { Frekuensi } \\
\text { gen }\end{array}$} \\
\hline & & Demak (20) & Magelang (20) & Pekalongan (20) & & \\
\hline \multirow[t]{3}{*}{$A l b$} & AA & 0,15 (3) & - & $0,10(2)$ & $0,08(5)$ & A: 0,39 \\
\hline & $\mathrm{AB}$ & $0,70(14)$ & $0,50(10)$ & $0,65(13)$ & $0,62(37)$ & B: 0,61 \\
\hline & BB & $0,15(3)$ & $0,50(10)$ & $0,25(5)$ & $0,30(18)$ & \\
\hline \multirow[t]{3}{*}{$C p$} & AA & $0,35(7)$ & $0,20(4)$ & $0,55(11)$ & $0,37(22)$ & A: 0,62 \\
\hline & $\mathrm{AB}$ & $0,55(11)$ & $0,50(10)$ & $0,45(9)$ & $0,50(30)$ & B: 0,38 \\
\hline & BB & $0,10(2)$ & $0,30(6)$ & - & $0,13(8)$ & \\
\hline \multirow[t]{3}{*}{$\mathrm{Tf}$} & AA & - & $0,10(2)$ & $0,10(2)$ & $0,07(4)$ & A: 0,32 \\
\hline & $\mathrm{AB}$ & $0,45(9)$ & $0,65(13)$ & $0,40(8)$ & $0,50(30)$ & B: 0,68 \\
\hline & BB & $0,55(11)$ & $0,25(5)$ & $0,50(10)$ & $0,43(26)$ & \\
\hline \multirow[t]{3}{*}{ Amy-I } & AA & $0,25(5)$ & $0,30(6)$ & $13(0,65)$ & $0,40(24)$ & A: 0,59 \\
\hline & $\mathrm{AB}$ & $0,55(11)$ & $0,35(7)$ & $5(0,25)$ & $0,38(23)$ & B: 0,41 \\
\hline & BB & $0,20(4)$ & $0,35(7)$ & $2(0,10)$ & $0,22(13)$ & \\
\hline
\end{tabular}

${ }^{1} \mathrm{Alb}=$ albumin; $\mathrm{C} \mathrm{p}=$ ceruloplasmin; $\mathrm{Tf}=$ transferin dan Am-I=amylase-I

Tabel 2. Heterosigositas Protein Darah Entok di Jawa Tengah

\begin{tabular}{lcccc}
\hline \multirow{2}{*}{ Kabupaten } & \multicolumn{5}{c}{ Lokus } \\
\cline { 2 - 5 } & Alb & Cp & Tf & Am-I \\
\hline Demak & 0,500 & 0,469 & 0,349 & 0,499 \\
Magelang & 0,375 & 0,495 & 0,489 & 0,499 \\
Pekalongan & 0,489 & 0,349 & 0,420 & 0,349 \\
\hline
\end{tabular}

\section{PEMBAHASAN}

\section{Identifikasi lokus albumin}

Berdasarkan pembacaan pita protein yang telah dilakukan, didapatkan hasil bahwa pada lokus Alb memiliki 2 alel yaitu alel A dan alel B. Hasil perhitungan frekuensi gen lokus Alb diketahui pada genotip $\mathrm{Alb}^{\mathrm{A}}$ sebesar 0,39 dan $\mathrm{Alb}^{\mathrm{B}}$ sebesar 0,61. Hasil penelitian berbeda dengan [19] pada entok lokal Nigeria yaitu terdapat empat alel pada lokus Alb yaitu alel A, B, C, dan D dengan frekuensi gen masing-masing 0.231; 0.294; 0.438 dan 0.038 .

Pada populasi entok Demak dan Pekalongan ditemukan dua alel yaitu A dan B yang membentuk karakter homosigot $A A$ dan $B B$ serta karakter heterosigot $A B$, sedangkan pada populasi entok Magelang hanya membentuk satu karakter homosigot BB dan karakter heterosigot AB. Penelitian [20] ditemukan karakter heterosigot dari tiga alel yaitu AB, AC, dan BC pada Itik Talang Benih. Penelitian pada ayam kedu ditemukan karakter homosigot BB dan CC serta karakter heterosigot $\mathrm{BC}[9]$.

\section{Identifikasi lokus ceruloplasmin}

Berdasarkan penelitian yang dilakukan, menunjukkan bahwa lokus $\mathrm{Cp}$ terletak setelah lokus Alb. Berdasarkan pembacaan pita protein, diketahui bahwa lokus $\mathrm{Cp}$ pada entok bersifat polimorfik yaitu memiliki alel $\mathrm{Cp}^{\mathrm{A}}$ dan $\mathrm{Cp}^{\mathrm{B}}$. Pita protein mampu membentuk karakter homosigot yaitu AA di tiga populasi dan BB di populasi Demak dan Magelang, serta karakter heterosigot yaitu $\mathrm{AB}$ di semua populasi. [21] pada melaporkan penemuan 5 macam genotip lokus $\mathrm{Cp}$ pada kelinci yaitu AA, BB, CC, AB dan BC. Hasil perhitungan frekuensi gen entok menunjukkan gen $C \mathrm{p}^{\mathrm{A}}$ memiliki nilai yang lebih besar $(0,62)$ dibandingkan dengan gen $C p^{B}(0,38)$. Hasil ini sesuai dengan penelitian [22] bahwa pada entok $\mathrm{Cp}^{\mathrm{A}}$ menunjukkan nilai yang paling besar yaitu 0,50 dibandingkan $C \mathrm{p}^{\mathrm{B}}$ dan $\mathrm{Cp}^{\mathrm{C}}$.

\section{Identifikasi lokus transferin}

Berdasarkan hasil identifikasi lokus Tf pada populasi entok Demak, Magelang dan Pekalongan memiliki dua alel yaitu A dan B. Hasil ini sesuai dengan [23] bahwa ditemukan dua alel pada lokus Tf pada itik Kerinci yaitu 

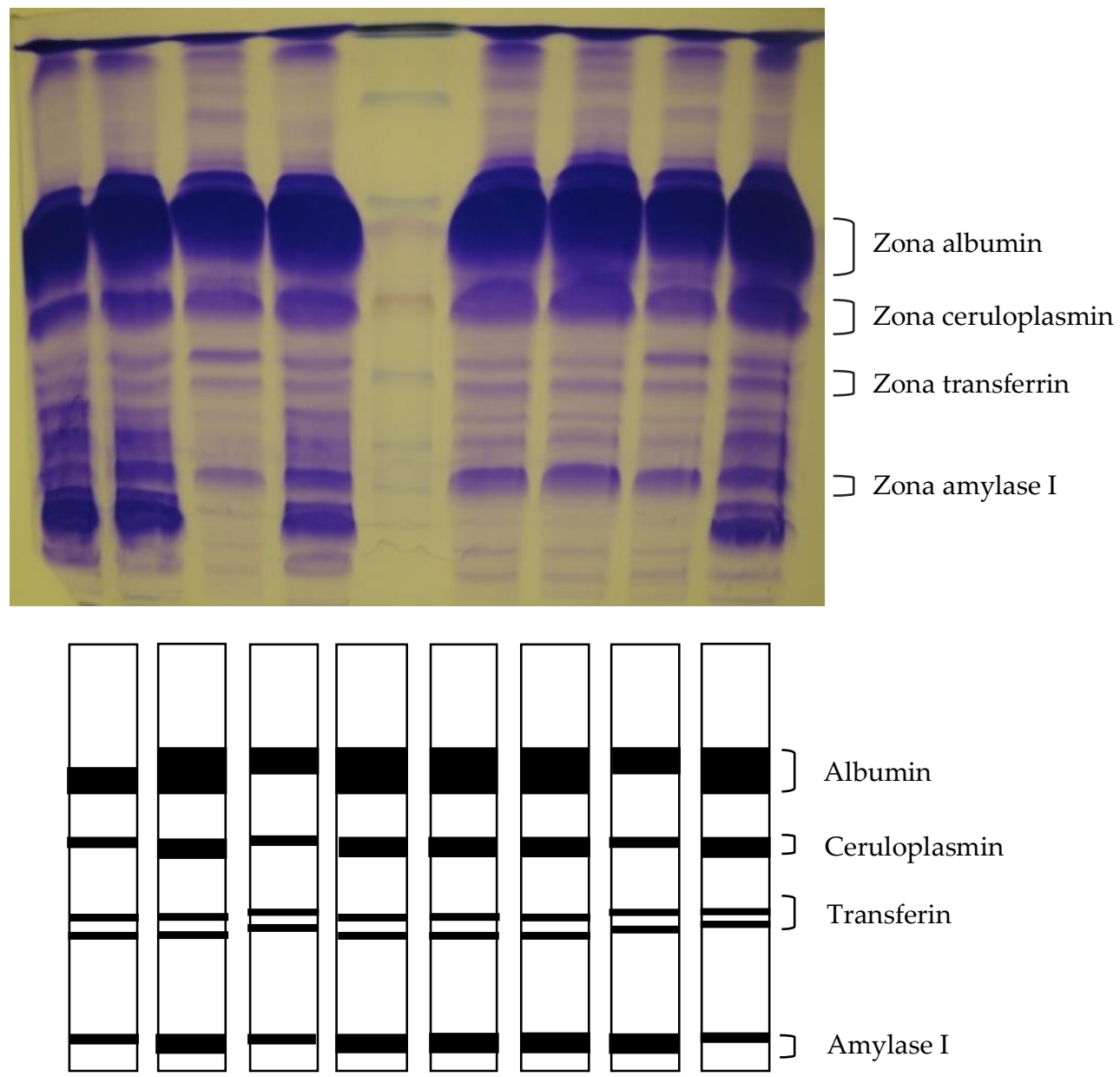

Albumin

Ceruloplasmin

Transferin

Gambar 1. Contoh pita protein hasil elektroforesis dan skater serum darah entok

alel A dan B. Populasi entok Magelang dan Pekalongan memiliki kedua alel yang mampu membentuk karakter homosigot, sedangkan pada populasi Demak hanya membentuk satu karakter homosigot yaitu BB. Namun, entok dari ketiga kabupaten mampu membentuk karakter heterosigot AB. [24] melaporkan variasi homosigot yang dibentuk adalah BB dan heterosigot adalah BC pada itik talang benih.

Hasil perhitungan frekuensi gen menunjukkan bahwa gen $\operatorname{Tf}^{\mathrm{A}} \mathrm{A}$ memiliki nilai sebesar 0,32 dan gen $\operatorname{Tf}^{\mathrm{B}}$ sebesar 0,68. [10] melaporkan hasil frekuensi gen tertinggi ditunjukkan pada gen $\mathrm{C}$ sebesar 0,50 bahwa pada itik Pegagan, sedangkan [24] melaporkan frekuensi tiga alel lokus Tf pada itik Tegal dengan frekuensi gen paling tinggi pada $\mathrm{B}(0,65)$. Frekuensi gen A pada itik Kerinci sebesar 0,8 dan gen $B$ sebesar 0,2 [23].

\section{Identifikasi lokus amylase I}

Populasi Entok Demak, Magelang, dan Pekalongan mampu membentuk alel A dan B menjadi karakter homosigot AA dan BB, serta karakter heterosigot $A B$. Hasil frekuensi gen Am-I pada entok yaitu gen A sebesar 0,59 dan gen $\mathrm{B}$ sebesar 0,41. Banyaknya keragaman pada protein darah menunjukkan bahwa karakter entok pada setiap populasi sangat bervariasi. Hasil ini sesuai penelitian [25] bahwa lokus Am-I mampu membentuk karakter homosigot $\mathrm{AA}$ dan $\mathrm{BB}$, serta karakter heterosigot yaitu $A B$ pada ayam kampung. Nilai frekuensi $A m-\mathrm{I}^{\mathrm{A}}$ menunjukkan angka yang lebih tinggi $(0,82)$ dibandingkan gen Am- $\mathrm{I}^{\mathrm{B}}(0,18)$.

\section{Heterosigositas pada entok}

Nilai Ho lokus Alb, Cp, Tf dan Am-I pada entok lebih tinggi dari penetian [20] yang melaporkan rata-rata nilai Ho pada Itik Talang 


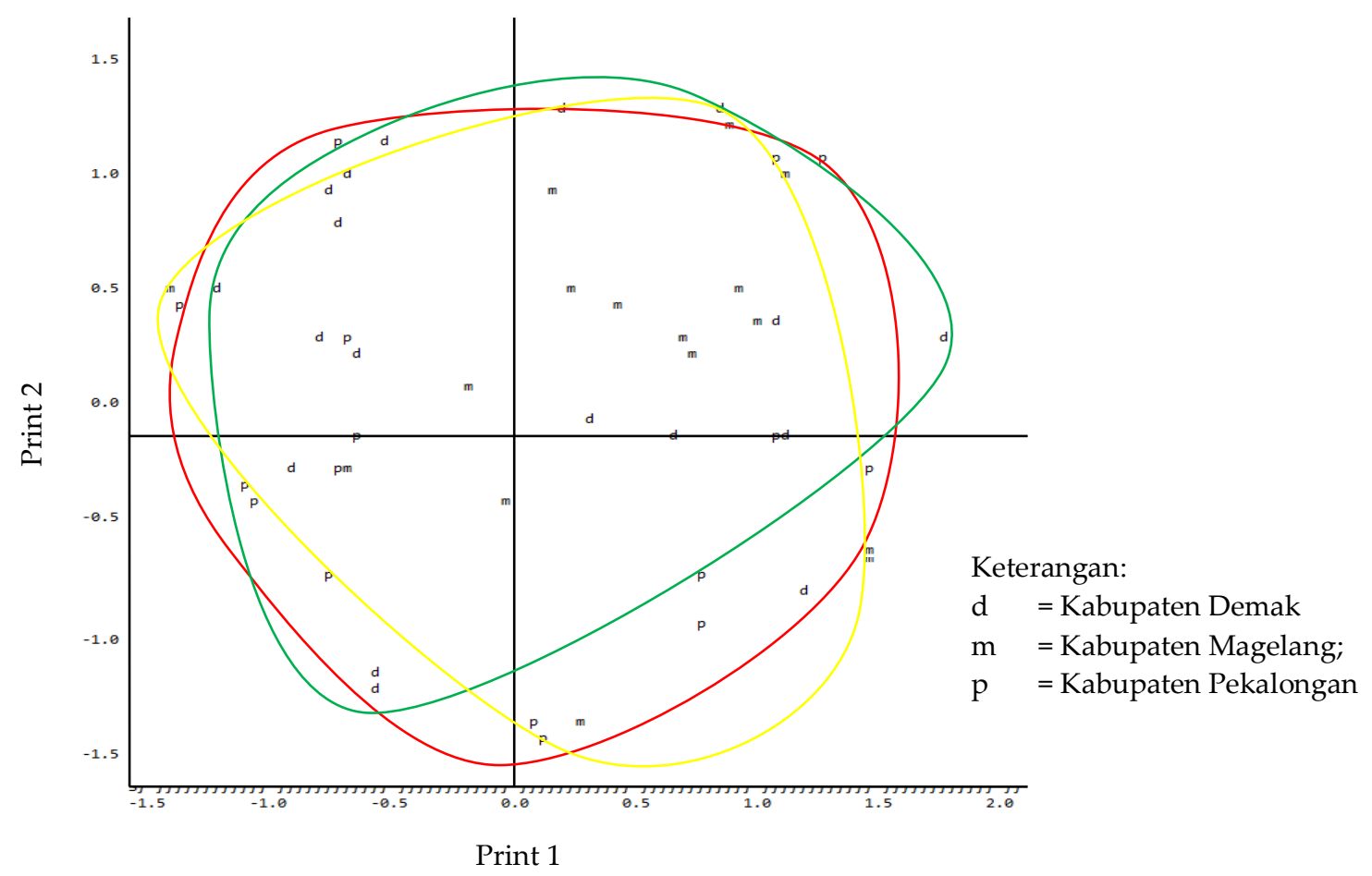

Gambar 2. Peta pengelompokkan entok berdasarkan polimorfisme darah

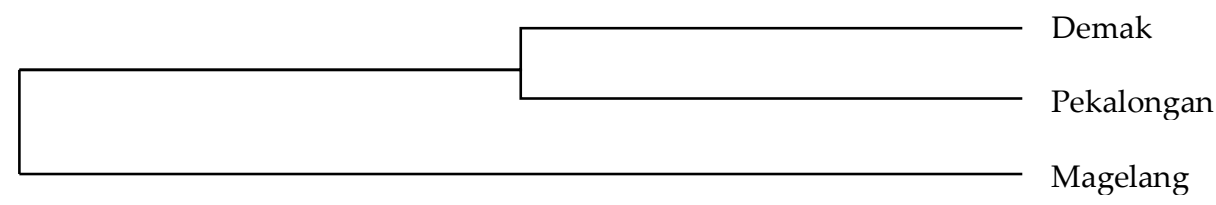

Gambar 3. Hasil analisis kekerabatan entok di Jawa Tengah

Benih sebesar 0,281. Nilai Ho yang rendah menunjukan bahwa sering terjadinya silang dalam suatu populasinya. Pemeliharaan keanekaragaman genetik dan heterosigositas akan menambah lebih banyak kesulitan sebagian populasi yang kecil.

Tinggi rendahnya nilai Ho merupakan acuan yang dapat digunakan untuk mengetahui hubungan kekerabatan suatu populasi. Sesuai dengan [26] bahwa nilai heterosigositas yang tinggi sangat menguntungkan karena semakin jauh hubungan kekerabatan kemungkinan terjadinya perkawinan silang dalam makin kecil dan kemunculan alel resesif menjadi rendah.

\section{Peta pengelompokkan dan jarak genetik}

Populasi entok di Kabupaten Pekalongan, Demak, dan Magelang menujukkan penyebaran yang merata. Hal ini mengindikasikan bahwa banyaknya kesamaan pada entok di tiga kabupaten yang dilihat berdasarkan sebaran genotip.

Populasi entok Demak memiliki kedekatan jarak genetik dengan populasi entok Pekalongan dibandingkan dengan populasi Magelang. Kedekatan jarak genetik dapat disebabkan kedekatan lokasi sehingga mengakibatkan terjadinya migrasi ternak dari daerah ke daerah lain [27]. Demak dan Pekalongan berada utara Jawa Tengah, sehingga memungkinkan terjadinya migrasi lebih mudah dibandingkan dengan kabupaten Magelang yang berada di selatan Jawa Tengah. Semakin dekat jarak genetik yang diperoleh menunjukkan adanya hubungan kekerabatan yang lebih dekat. [28] melaporkan bahwa kedekatan hubungan kekerabatan yang terjadi dapat dikarenakan adanya komposisi genetik yang spesifik dengan interaksi pada kondisi lingkungan. 


\section{KESIMPULAN}

Lokus albumin, ceruloplasmin, transferin dan amylase-I, pada tiga populasi entok bersifat polimorfik. Populasi entok di Jawa Tengah menunjukkan keragaman yang rendah berdasarkan hasil polimorfisme protein darah dan rendahnya nilai heterosigositas. Entok di kabupaten Demak menunjukkan hubungan kekerabatan yang lebih dekat dengan kabupaten Pekalongan.

\section{KONFLIK KEPENTINGAN}

Penulis mendeklarasikan bahwa tidak ada konflik kepentingan dengan pihak lain mengenai pendanaan dan obyek penelitian.

\section{DAFTAR PUSTAKA}

1. Kementan. 2017. Data statistik produksi daging nasional. Jakarta (Indonesia): Kementerian Pertanian.

2. Fatmarischa, N., S. Sutopo, and S. Johari. 2013. Ukuran tubuh entok di tiga kabupaten provinsi Jawa Tengah. Sains Peternakan. 11(2):106-112. Doi: 10.20961/ sainspet.v11i2.4858.

3. Steklenev EP. 1990. Genetic variability of amylase isozymes of hybrids between Muscovy duck (Cairina moschata) and domestic Pekin duck (Anas platyrhynchos) in comparison with the initial species. Steppe Region (Ukrainian): Ukrainian Research Institute of Animal Husbandry of Steppe Region.

4. Solomon JKQ, Austin R, Cumberbatch RN, Gonsalves J, Seaforth E. 2006. A comparison of live weight and carcass gain of Pekin, Kunshan, and Muscovy ducks on a commercial ration. Livest. Res. Rural Dev. 18:154.

5. Dikken, G.D. and S.J. van der Meulen. 2004. Duck keeping in the tropics. Agromisa/ Technical Centre for Agricultural and Rural Cooperation. FAO.

6. Ceriotti, G., A. Caroli, R. Rizzi, and C. Crimella. 2003. Genetic relationships among taurine (Bos taurus) and Zebu (Bos indicus) populations as revealed by blood groups and blood proteins. J. Anim. Breed.
Genet. $\quad$ 120:57-67. Doi: 10.1046/j.14390388.2003.00379.x

7. Rege, J.E.O., and A.M. Okeyo. 2011. Improving our knowledge of tropical indigenous animal genetic resources. Proc. Animal genetics training resource, version 3, Uppsala, Sweden.

8. Astuti, M. 1997. Estimasi jarak genetik antar populasi kambing Kacang, kambing Peranakan Etawah dan kambing lokal berdasarkan polimorfisme protein darah. Buletin Peternakan. 21(1):1-9. Doi: 10.21059/buletinpeternak.v21i1.1668

9. Johari, S., S. Sutopo, E. Kurnianto, and E. Hasviara. 2008. Blood protein polymorphism of Kedu Chicken. J. Indones. Trop. Anim. Agric. 33(4):313-318.

10.Sari, M.L., R.R. Noor, P.S. Hardjosworo, and C. Nisa. 2011. Polimorfisme protein darah itik pegagan dengan metode PAGE. J. Agripet. 11(2):58-62. Doi: 10.17969/ agripet.v11i2.376

11. Noviani, F., S. Sutopo, dan E. Kurnianto. 2013. Hubungan genetik antara domba Wonosobo (Dombos), domba Ekor Tipis (DET) dan domba Batur (Dombat) melalui analisis polimorfisme protein darah. Sains Peternakan. 11(1):1-9. Doi: 10.20961/ sainspet.v11i1.4798

12. Yuwono, T., I. Sumeidiana, Y.S. Ondho, and E. Kurnianto. 2016. Polimorfisme protein serum darah induk sapi beranak kembar dan tunggal pada sapi Peranakan Ongole dan Keturunan Simental. Jurnal Veteriner. 17(4):510-516. Doi: 10.19087/ jveteriner.2016.17.4.510

13. Sutiyono, S., S. Sutopo, Y.S. Ondho, E.T. Setiatin, D. Samsudewa, A. Suryawijaya, D.A. Lestari, and E. Kurnianto. 2018. Genetic diversity of Ongole Grade cattle of Rembang District, Central Java, Indonesia, based on blood protein polymorphism. Biodiversitas. 19(4):1429-1433. Doi: 10.13057/biodiv/d190432

14. Martoenus, A. dan T. F. Djatmikowati. 2015. Teknik pengambilan darah pada beberapa hewan. Diagnosa veteriner. 14(1):6-12.

15. Ogita, Z.I. and C.L. Markert. 1968. A Miniaturizedsystem for electrophoresis on polyacrilamide gels. Anal. Biochem. 99:233-241. 
16. Warwick, E.J., J.M. Astuti, and W. Hardjosoebroto. 1995. Pemuliaan ternak. Edisi ke-5. Gadjah Mada University Press, Yogyakarta.

17. Nei. M. 1987. Molecular evolutionary genetics. Colombia University Press, New York.

18. Nei, M. 1972. Genetics distance between populations. Am. Naturalist. 106:283-292.

19. Oguntunji, O. dan K. L. Ayorinde. 2015. Blood protein polymorphism and genetic diversity in locally adapted Muscovy duck (Cairina moschata) in Nigeria. Anim. Genet. Resour. 56:9-18.

20. Azmi, A., G. Gunawan dan E. Suharnas. 2006. Karakteristik Morfologis dan Genetik Itik Talang Benih di Bengkulu. Prosiding: Seminar Nasional Teknologi Peternakan dan Veteriner. 2006:716-722.

21. Bezova, K., J. Rafay, J. Mojto, and A. Trakovicka. 2007. Analysis of genetic polymorphism of blood proteins and selected meat quality traits in rabbits. Slovak J. Anim. Sci. 40(2):57-62.

22. Sutiyono, B. 2012. Performan genetik dan bioreproduksi hasil persilangan itik (Anas Platyrhynchos) dengan entok (Cairina Moschata) sebagai dasar perkembangbiakan. Disertasi Doktor. Universitas Diponegoro, Semarang.

23. Nur, H., Y. Yusrizal, and F. Manin. 2012. Study of blood polymorphism of Kerinci duck. Int. J. Poult. Sci. 11(10): 641-643. Doi: 10.3923/ijps.2012.641.643

24. Ismoyowati. 2008. Kajian deteksi produksi telur itik Tegal melalui polimorfisme protein darah. Anim. Prod. 10(2): 122-128.

25. Hashiguchi, T., T. Nishida, Y. Hayashi, Y. Maeda, and S.S. Mansjoer. 1993. Blood protein polymorphisms of native and jungle fowls in Indonesia. Asian Australas. J. Anim. Sci. 6(1):27-35. Doi: 10.5713/ ajas.1993.27

26. Noor, R.R. 1996. Genetika ternak. Penebar Swadaya, Jakarta.

27. Johari, S., S. Ekasari and E. Kurnianto. Genetic variation in three breeds of Indonesian local ducks based on blood and egg white protein polymorphisme. J. Indones. Trop. Anim. Agric. 38(1):20-26. Doi: 10.14710/jitaa.38.1.20-26

28. El-Gendy, E. A., M. A. Helal, N. H. Goher, and A. Mostageer. 2005. Molecular characterization of genetic biodiversity in ducks, using RAPD-PCR analysis. Arab J. Biotech. 8 (2): 253-264. 